\title{
Artificial Intelligence Implementation Of Rough Set In Decision System Unemployments
}

\author{
Rezki Fauzi $^{1}$, M.Arif Rahman ${ }^{2}$ \\ ${ }^{1}$ Program Studi Sistem Informasi Fakultas Teknik Universitas Nahdlatul Ulama SUMBAR \\ ${ }^{2}$ Program Studi Manajemen Informatika AMIK Datuk Parpatih Nan Sabatang
}

( ${ }^{1}$ Jl. S.Parman No.119 Ulak Karang, Padang, Sumatera Barat, telp. 082386898632)

$\left({ }^{2} J 1\right.$. Patimura No 11 C-D, Padang, Sumatera Barat, telp. 082389105050) e-mail: ${ }^{1}$ drezkifauzi@gmail.com, ${ }^{2}$ marifrahman@gmail.com

\begin{abstract}
Abstrak
Penelitian ini bertujuan bagaimana pengambilan keputusan bagi pencari kerja yang menyebabkan mereka berada pada antrian pengangguran. Semoga dengan diterapkan ini kepada pencari kerja diharapkan ada perbaikan bagi nasib mereka di dunia kerja. Akan tetapi banyak pencari kerja tidak menyadari pentingnya kompetensi dan mental yang baik sebagai syarat utama sukses berkarier. Hasil analisis diharapkan dapat dijadikan pedoman pengambilan keputusan bagi pencari kerja dan perusahaan. Calon pencari kerja yang telah diuji berasal dari pendidikan Sarjana (S1), Ahli Madya (D3) dan SMA/SMK kota Padang berjumlah 100 orang. Penelitian ini menggunakan kuisoner baik online maupun offline dan wawancara/interview sebagai alat pengumpul data dan metode Rough Set sebagai metode analisis pengujian kriteria. Data analisis menggunakan aplikasi Rosseta 1.4.4.1. Penelitian ini menunjukkan keputusan yang menghasilkan pengetahuan baru (1) uji kompetensi (2) uji diagnosa mental yang mudah- mudahan membantu pihak terkait penelitian ini. Hasil penelitian baik metode Rough Set maupun tools rosseta 1.4.41 didapatkan rule rule yang dihasilkan 7 reduce diekstraksi menjadi 21 general rules metode Rough Set dan tools rosseta 1.4.4.1 knowledge 31 general rules sehingga sudah optimal dalam menghasilkan suatu pengetahuan baru.
\end{abstract}

Kata Kunci: Data mining, Rough Set, Pencari kerja, Pendidikan, Diagnosa Mental

\begin{abstract}
The main objective of this study explain how to make decision of the applicant cause them in the line of unemployment. Base on of the study, hopefully that applicant able to improve their skills in order to accept them in the work place. Nevertheless, almost of a ware how important competence and mental skill as main requirement to be successful carier in workplace. The result of study is expected become a guide in making decision for applicantto apply the job in the company.Prospective applicant are taken from different educational background in Padang West Sumatera. The Totally of applicant one hundred person. This study use a question naire and interview as a tool for collecting data and the method Rough Set as method of analysis. Data were analyzed using Rosseta 1.4.4.1 application. This research shows the result in maining decision as follow (1)compentence (2) mentality diagnosis test, by un understanding the variables that the applicant will know how important the variable so the can improve the competence and mentality skill to be accepted in workplace The results of good research methods and tools Rough Set rule obtained rosseta 04/01/41 rule generated 7 Reduced extracted into 21 general rules and methods of Rough Set of tools rosseta 1.4.4.1 knowledge of general rules that were optimal in producing a new knowledge.
\end{abstract}

Keywords: Data Mining, Rough Set, Unemployments, Education, Competence,Detector Mental. 


\section{PENDAHULUAN}

Sumber daya manusia atau sering disebut dengan human resources merupakan penduduk secara keseluruhan. Dari segi penduduk sebagai faktor produksi, maka tidak semua penduduk dapat bertindak sebagai faktor produksi, hanya penduduk yang berupa tenaga kerja (man power) yang dapat dianggap sebagai faktor produksi.

Tenaga kerja mencakup penduduk yang sudah bekerja atau sedang bekerja, yang sedang mencari pekerjaan, dan yang sedang melakukan kegiatan lain, seperti bersekolah dan mengurus rumah tangga. Perserikatan Bangsa-Bangsa (PBB) menggolongkan penduduk usia 15-64 tahun sebagai tenaga kerja. Konsep dari tenaga kerja terdiri dari angkatan kerja dan bukan angkatan kerja. Angkatan kerja (labour force) merupakan bagian dari tenaga kerja yang sesungguhnya terlihat atau berusaha untuk terlibat [5].

Penyebab utama pengangguran terdiri dua faktor yaitu faktor Internal dan faktor Eksternal. Faktor Eksternal yaitu perusahaan, lembaga, kantor yang menjadi penampung pekerja. Dalam hal ini pihak eksternal tentu akan memilih calon pekerja yang potensial dan siap pakai dengan kriteria khusus yang sudah distandarisasikan perusahaan mereka, yang pasti mereka tidak menerima pencari kerja yang coba- coba. Faktor Internal yaitu potensi pencari kerja yang tidak mampu memenuhi persyaratan yang dibutuhkan pihak Eksternal seperti tidak memiliki kemampuan (prestasi khusus), kemampuan untuk bersaing (tidak kompetitif), tidak memiliki penguasaan bahasa asing, information Teknologi (IT), tidak memiliki mental dan kepribadian yang baik (sikap), serta tidak memiliki keberanian untuk mencoba sesuatu pekerjaan yang baru (pilih-pilih kerja). Dari hasil penelitian sebelumnya menyimpulkan ternyata tingginya penyebab angka pengangguran itu disebabkan oleh lemahnya kompetensi si pemilik nilai itu sendiri yaitu SIMKA (Skill, Iman, Mental, Komunikasi).

Menurut Data Badan Pusat Statistik, Kota Padang, Sumatera Barat, mencatat sebanyak 11.803 pencari kerja tahun 2016 [7], 10.293 pencari kerja tahun 2017 [8], dan 11.811 pencari kerja tahun 2018 [9], begitulah realitanya. Dari jumlah data- data dari pencari kerja maka ditetapkan parameter- parameter agar dapat diketahui kriteria- kriteria penyebab pengangguran dengan membangun sebuah rule atau aturan data mining untuk dapat pengetahuan baru proses ekstraksi. Dengan Artificial Intelligent Metode Rough Set kami mencoba membuat polapola aturan tertentu dan juga menguji untuk mengambil keputusan yang menjadi penyebab pengangguran pencari kerja yang akan menuju dunia kerja.

Data mining juga diartikan sebagai pengekstraan informasi baru yang diambil dari bongkahan data besar yang membantu dalam pengambilan keputusan [4]. Data Mining cukup banyak penerapannya yang ditunjang kekayaan dan keanekaragaman berbagai bidang ilmu seperti artificial intelligence, database, statistic, permodelan matematika, pengolahan citra, dan sebagainya [1]

Data Mining juga diartikan sebagai pengekstrakan informasi baru yang diambil dari bongkahan data besar yang membantu dalam pengambilan keputusan $[9,14]$. Data Mining atau dalam jurnal ilmiah juga dikenal dengan nama Knowledge Discovery in Database (KDD) cukup banyak penerapannya yang ditunjang kekayaan dan keanekaragaman berbagai bidang ilmu seperti artificial intelligence, database, statistik, permodelan matematika, pengolahan citra, dan sebagainya $[1,3]$.

Metode Rough Set pertama kali dikenalkan oleh Zdizslaw Pawlak. Fungsinya adalah sebagai alat matematikal guna mengatasi masalah ketidakpastian dan ketidakjelasan. Telah berhasil diterapkan dalam berbagai tugas, seperti fitur seleksi/ekstraksi, sintesis aturan dan klasifikasi, penemuan pengetahuan, dan lain-lain. Menurut Pawlak, Rough Set sebagai sarana baru untuk membedakan ekstensi dan generalisasi. Dari proses perbedaan ekstensi tersebut dihasilkan rule yang sesuai dengan kriteria yang diuji pelamar kerja atau pencari kerja. Untuk mengetahui rules yang dihasilkan tools Rosseta 1.4.4.1, dapat dilihat dari hasil reduct yang dihasilkan $[5,6]$.

Artificial Intelligence atau kecerdasan buatan (AI) adalah teknik yang digunakan untuk meniru kecerdasan yang dimiliki oleh makhluk hidup maupun benda mati untuk menyelesaikan 
sebuah persoalan. Pendekatan yang digunakan dapat dilakukan dengan metode sistem logika tidak kaku (FL), sistem evolusi (EC), dan generalisasi dengan pembelajaran mesin (ML) [2].

Urgensi penelitian ini sangat diperlukan dalam memahami sejauh mana keterkaitan Data Mining dan teknik Artificial Inteligent Rough Set dari proses kriteria yang telah ditentukan untuk pencari kerja, menggali pengetahuan yang terpendam dalam sistem informasi dengan menggunakan teknik Artificial Inteligent Rought Set, sehingga dapat mendeteksi sejak dini apa saja yang melatarbelakangi masih tingginya tingkat pengangguran bagi pencari kerja.

\section{METODE PENELITIAN}

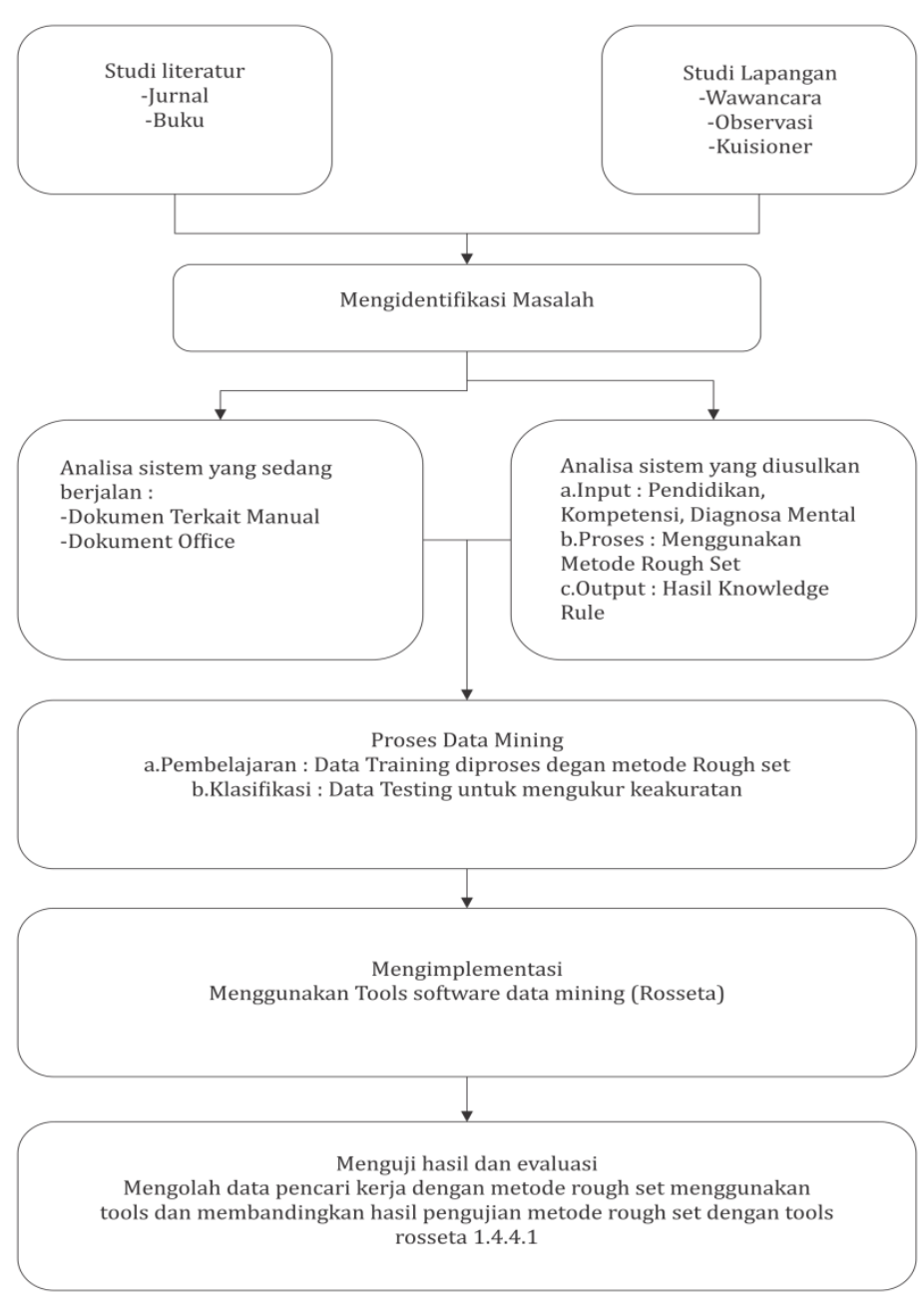

Gambar 1. Metode Penelitian

\subsection{Studi Literatur}

Studi adapun pelajari literatur -literatur yang mendukung topik penelitian yang sedang diteliti yang langsung di pinjamkan berupa buku Exclusive UK- PMDK (Uji Kelayakan Pembekalan Menuju Dunia Kerja) oleh Ketua Yayasan AMAN. Literatur diambil dari internet, yang berupa artikel dan jurnal ilmiah tentang Metode Rough Set dan software Rosseta 1.4.4.1, serta bahan bacaan lain yang mendukung penelitian. 


\subsection{Studi Lapangan}

Metode Pengumpulan Data yaitu dalam melakukan pengumpulan data, metode yang digunakan untuk mengumpulkan data tersebut adalah tinjauan Lapangan yaitu peneliti langsung mendatangi pihak yang berhubungan dengan data-data yang diperlukan peneliti, seperti data pencari kerja selama penelitian berlangsung. Observasi yaitu data langsung diminta ke pihak Yayasan AMAN dan Dinas Tenaga Kerja dan Perindustrian (Disnaker) di Padang. Questioner yaitu melakukan Questioner langsung dengan pencari kerja dengan para Peneliti dan Konsultan Yayasan AMAN dengan memberikan penyuluhan pencari kerja (PPK).

\subsection{Mengidentifikasi Masalah}

Tahap ini merupakan langkah awal untuk menemukan tujuan dan rumusan masalah serta penerapan Metode Rough Set untuk menentukan kriteria penilaian calon pencari kerja baik itu Pendidikan Terakhir, Kompetensi dan Diagnosa Mental. Untuk dapat memahami dan menganalisis masalah yang ada maka analisis masalah ini dibagi dalam 2 kategori yaitu :

a) Analisis sistem yang sedang berjalan yaitu memberikan Questioner yang nantinya akan diisi oleh pencari kerja baik online maupun offline (tatap muka)

b) Analisis sistem yang diusulkan yaitu menganalisis data-data : Pendidikan Terakhir Pencari Kerja, Jumlah pencari kerja yang melamar pada dinas tenaga kerja dan perindustrian dan lembaga Yayasan AMAN, jumlah pencari kerja yang menyatakan siap hadir dan interview sesuai jadwal yang ditentukan.

\subsection{Mengimplementasi Sistem}

Melakukan analisis menggunakan metoda yang dipilih yaitu Rough Set dengan melakukan perhitungan secara manual terhadap nilai kompetensi dan diagnosa mental yang diperoleh dari setiap kecendrungan kemunculan data pada setiap variabel dari atribut dengan menggunakan data sampel sebagai data Training dan data Testing yang diambil sebagian dari seluruh data dan selanjutnya menguji hasil perhitungan manual dengan menggunakan Software Data Mining. Implementasi dilakukan untuk dianalisis dengan Rough Set menggunakan Software Data Mining yaitu Rosseta.

\subsection{Menguji Hasil dan Evaluasi}

Menguji hasil dilakukan dengan melakukan pengujian terhadap hasil yang diperoleh dengan cara menginputkan data ke teori Rough Set dengan berupa formula umum. Nantinya dari formula tersebut kita akan mendapatkan hasil berupa rule untuk pengambilan keputusan. Data ini akan kita hitung secara manual dan apabila hasil yang kita dapat sesuai, berarti perhitungan tersebut dapat dikatakan baik namun masih perlu untuk diuji menggunakan Software Data Mining dengan data lain. Implementasi dilakukan menggunakan Software Data Mining yaitu Rosseta,juga Hardware serta Software pendukung yang Compatible. Hasil implementasi berupa beberapa informasi yang berkaitan dengan hasil keputusan bagi pencari kerja. 


\section{HASIL DAN PEMBAHASAN}

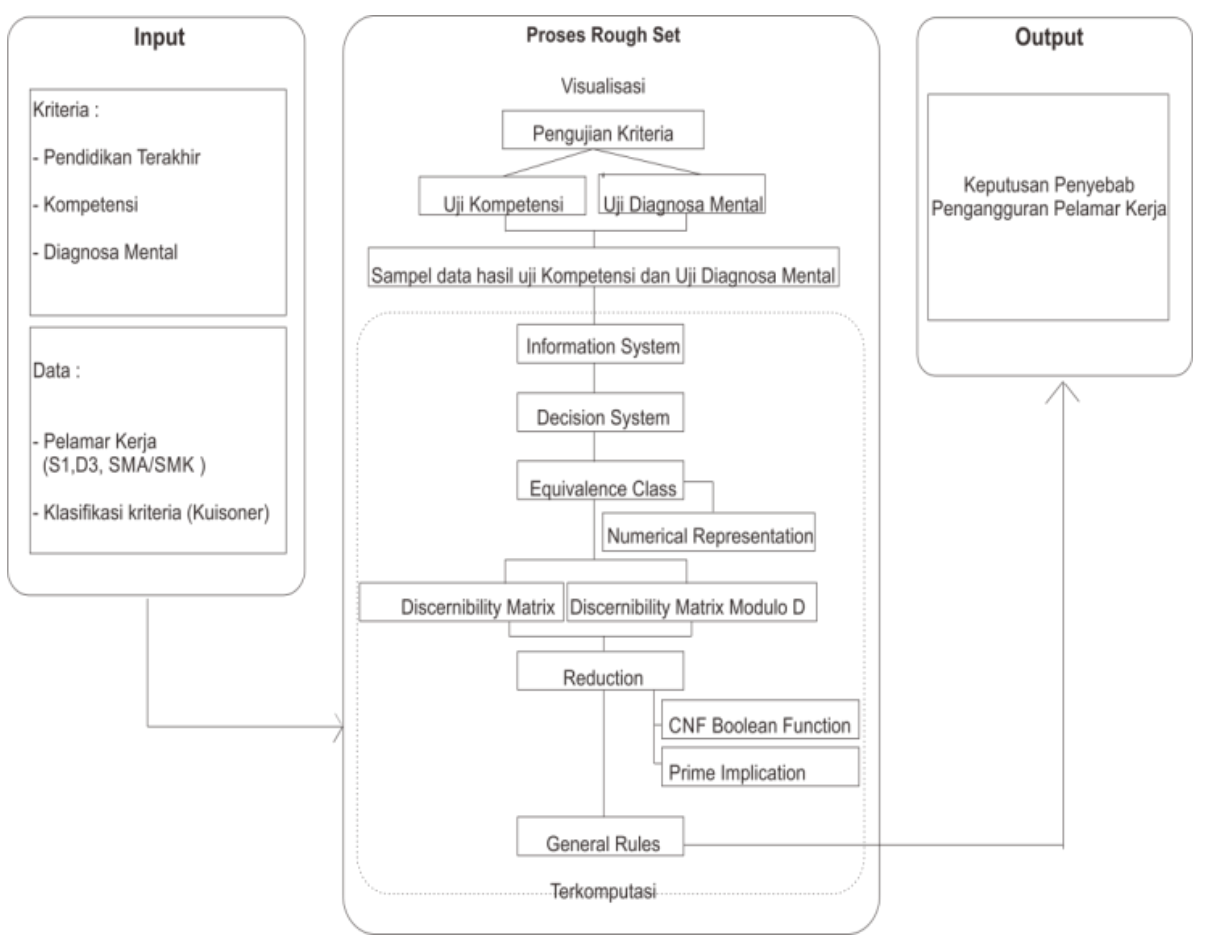

Gambar 2. Model Konseptual Sistem Keputusan

Model konseptual diatas terdiri dari :

a. Input

Input atau masukan data yang digunakan pada penelitian ini diantaranya data pencari kerja, klasifikasi kriteria data pengujian kompetensi dan data pengujian uji diagnosa mental baik itu melalui tertulis (kuisoner) maupun langsung interview/wawancara

b. Proses Rough Set

Proses Rough Set yang dilakukan pada penelitian ini, yang bertujuan untuk menentukan rule- rule dari pencari kerja dalam pengambilan keputusan apa yang menjadi penyebab pengangguran dimulai pengujian kriteria baik kriteria uji kompetensi dan uji diagnosa mental yang sudah ditentukan skala data. Menurut [10] skala ialah ukuran majemuk yang terdiri dari beberapa butiran (item) yang memiliki struktur empiris atau logis. Dari skala data tersebut dijadikan sebuah data sampel dari sekumpulan data yang akan digunakan sebagai information system dan decision system untuk merepresentasikan objek, atribut kondisi dan atribut keputusan yaitu objeknya pencari kerja, kriteria pendidikan, kriteria kompetensi dan kriteria diagnosa mental.

Selanjutnya dari sekumpulan data yang sudah di presentasikan decision system dikelompokkan atau filterisasi untuk setiap objek - objek yang mempunyai kriteria atribut yang sama lalu dijumlahkan dan dikelompokkan dalam bentuk class yang sama agar proses teknik cleaning menjadi sederhana itulah yang disebut proses equivalence class. Dilanjutkan Discerbility matrix dan Discerbility matrix Modulo D akan membandingkan sekumpulan atribut berdasarkan dari equivalence class yang akan dimodelkan dengan Pendidikan dimodelkan "A", Kompetensi dimodelkan "B" dan Diagnosa Mental dimodelkan "C. Tahap ini bertujuan mendapatkan hasil dari sistem ini berdasarkan reduct penyeleksian atribut dari sekumpulan atribut kondisi menggunakan prime implican fungsi Boolean dari Discernibility Matrix Modulo D menghasilkan class -class tertentu 


\section{Output}

Penentuan keputusan penyebab pengangguran pencari kerja yaitu setelah mendapatkan reduct maka dapat ditarik sebuah kesimpulan rule - rule dari semua kelas yang menghasilkan keputusan penyebab pengangguran bagi pencari kerja dari proses Rough Set.

\subsection{Analisis Kebutuhan Data}

Kebutuhan akan kriteria penting dalam pengambilan keputusan yang akan digunakan metode Rough Set. Untuk menentukan kriteria diperlukan beberapa tahap

a. Melakukan interview dan wawancara langsung dengan calon pencari kerja.Wawancara yang dilakukan menggunakan wawancara tidak tersetruktur karena hanya ingin mendapatkan informasi tambahan atau garis besar permasalahan dari responden yang telah mengisi kuisioner.

b. Membuat Kuisoner untuk calon pencari kerja. kuisioner merupakan teknik pemgumpulan data yang dilakukan dengan cara memberi seperangkat pertanyaan tertulis kepada responden untuk menjawabnya baik online melalui google form maupun lansung ke pencari kerja bersangkutan. Dalam penelitian ini kuisioner digunakan untuk mengumpulkan data dari para responden yang telah ditentukan. Kuisioner berisi pertanyaan yang menyangkut tentang tanggapan calon pencari kerja terhadap soal kompetensi dan detector tabel yang berisi 30 penyakit mental saat ini. Untuk selanjutnya dibagikan ke calon pencari kerja guna mendapatkan kriteria.

Setelah melakukan serangkaian kegiatan diatas adapun kriteria yang digunakan dalam menseleksi calon pencari kerja :

1. Pendidikan

2. Kompetensi

3. Diagnosa Mental

\subsection{Analisis Pengujian Kompetensi}

Berdasarkan pertanyaan untuk uji kompetensi sebanyak 11 soal yang dibuat kemudian divalidasi menggunakan SPSS versi 25 maka hanya 10 soal yang korelasi valid dan reability valid ,ada 2 metode digunakan yaitu skala gutman dan rating scale. Skala gutman untuk soal yang membutuhkan jawaban pasti terhadap variable yang dijabarkan, nilai yang diberikan hanya bilangan biner 1 dan 0 dari tiap tiap jawaban yg memenuhi syarat dengan nilai tertinggi 1 sedangkan rating scale adalah pertanyaan tertutup dimana membutuhkan uraian panjang dan penjelasan terhadap pertanyaan yang diberikan, skor mulai dari 1,2,3, 4,dan 5 nilai tertinggi adalah 5.Diuraikan tabel dibawah ini.

TABEL 1. Butir Soal Uji Kompetensi

\begin{tabular}{llllll}
\hline No & Butir Soal & Jumlah & $\begin{array}{l}\text { Skor } \\
\text { Tertinggi }\end{array}$ & Total skor & Metode \\
\hline 1 & $1,2,3,4,5,7$ & 6 & 5 & 30 & $\begin{array}{l}\text { Rating } \\
\text { Scale } \\
\text { Skala } \\
\text { Gutman }\end{array}$ \\
& $6,8,9,10$ & 4 & 1 & 4 & \\
\hline
\end{tabular}

Dari sampel 200 pencari kerja hanya 100 pencari kerja yang datanya dibutuhkan untuk analisis data karena cukup valid dan reabilitynya bisa digunakan. Sehingga keputusan untuk memenuhi jawaban pencari kerja yang dibutuhkan instansi terkait dibuatkan 2 interval 
kompetensi yaitu jika total keseluruhan jawaban kurang atau sama dengan 17 maka calon pencari kerja tidak memiliki kompetensi sedangkan jika total skor melebihi 17 maka dikatakan ada kompetensi.

TABEL 2. Interval Uji Kompetensi

\begin{tabular}{ll}
\hline Interval Kompetensi & Indikator \\
\hline$<=17$ & Tidak ada kompetensi \\
$>17$ & Ada Kompetensi \\
\hline
\end{tabular}

\subsection{Analisis Pengujian Detection Tabel (Diagnosa mental)}

Berdasarkan pertanyaan detection tabel berupa 30 penyakit mental penyebab masalah yang sudah divalidasi menggunakan SPSS V25. Data yang digunakan yaitu setiap poin poin dari 30 penyakit mental penyebab masalah yang ditandai sesuai kondisi saat ini pencari kerja yang akan dijadikan acuan dalam proses pengambil keputusan oleh instansi terkait. Setiap keputusan yang memnuhi kebutuhan pihak instansi akan dibuatkan skala Gutman yang diolah dengan menjumlah total penyakit mental yang dilingkari sesuai hitungan skala yang sudah ditentukan dengan jelas dan pasti. serta 3 tambahan soal pertanyaan untuk menguatkan kondisi mental pencari kerja dalam melamar kerja.Berikut Interval dan indicator mental dengan jumlah skor yang sudah ditentukan.

TABEL 3. Interval Detection Tabel

\begin{tabular}{ll}
\hline Interval Mental & Indikator \\
\hline $0<=10$ & Ringan \\
$>10<=20$ & Sedang \\
$>20<=30$ & Berat
\end{tabular}

\subsection{Pengelolan Data Mining}

Data mining merupakan proses menemukan pola pola dalam data, biasanya menggunakan data yang besar.berikut pola pola proses dengan teknik Rough Set dalam mempresentasikan data pencari kerja sebagai information system dari Microsoft excel

\subsection{Sampel data proses Data mining (Information system)}

TABEL 4. Sampel Proses Data Mining

\begin{tabular}{|c|c|c|c|c|}
\hline No & Nama & Pendidikan & Kompetensi & Diagnosa Mental \\
\hline 1 & PKR1 & SMA & Ada & Ringan \\
\hline 2 & PKR2 & SMA & Ada & Ringan \\
\hline 3 & PKR3 & SMA & Ada & Berat \\
\hline 4 & PKR4 & SMK & Tidak & Ringan \\
\hline 5 & PKR5 & SMK & Tidak & Ringan \\
\hline
\end{tabular}




\begin{tabular}{rllll}
6 & PKR6 & D3 & Ada & Ringan \\
7 & PKR7 & D3 & Ada & Sedang \\
8 & PKR8 & D3 & Tidak & Sedang \\
9 & PKR9 & D3 & Tidak & Ringan \\
10 & PKR10 & S1 & Ada & Ringan \\
11 & PKR11 & S1 & Tidak & Ringan \\
12 & PKR12 & S1 & Ada & Berat \\
\hline
\end{tabular}

PKR=Pencari Kerja

\subsection{Penerapan Metode Rough Set}

Berdasarkan pertanyaan detection tabel berupa 30 penyakit mental penyebab masalah yang sudah divalidasi menggunakan SPSS V25.Data yang digunakan yaitu setiap poin poin dari 30 penyakit mental penyebab masalah yang ditandai sesuai kondisi saat ini pencari kerja yang akan dijadikan acuan dalam proses pengambil keputusan oleh instansi terkait.Setiap keputusan yang memnuhi kebutuhan pihak instansi akan dibuatkan skala Gutman yang diolah dengan menjumlah total penyakit mental yang dilingkari sesuai hitungan skala yang sudah ditentukan dengan jelas dan pasti.serta 3 tambahan soal pertanyaan untuk menguatkan kondisi mental pencari kerja dalam melamar kerja.Berikut Interval dan indicator mental dengan jumlah skor yang sudah ditentukan.

\subsection{Analisis Pengujian Metode Rough Set}

a. Decision System

Rough Set menawarkan dua bentuk presentasi data yaitu information system (IS) dan Decision System (DC) dimana "U" anggota bilangan $\{$ “c1,c2,c3,..CC $\}$ " sebagai objek seperti $\{$ objek 1 ,objek 2 ,objek $-\mathrm{n}\}$ dan "A" $\{\mathrm{a} 1, \mathrm{a} 2, \ldots \mathrm{an}\}$

TABEL 5. Data Decision System

\begin{tabular}{rllllc}
\hline No & Nama & Pendidikan & Kompetensi & Diagnosa Mental & Keputusan \\
\hline 1 & PKR1 & SMA & Ada & Ringan & Terima \\
2 & PKR2 & SMA & Ada & Ringan & Tolak \\
3 & PKR3 & SMA & Ada & Berat & Terima \\
4 & PKR4 & SMK & Tidak & Ringan & Tolak \\
5 & PKR5 & SMK & Tidak & Ringan & Terima \\
6 & PKR6 & D3 & Ada & Ringan & Terima \\
7 & PKR7 & D3 & Ada & Sedang & Tolak \\
8 & PKR8 & D3 & Tidak & Sedang & Tolak \\
9 & PKR9 & D3 & Tidak & Ringan & Tolak \\
10 & PKR10 & S1 & Ada & Ringan & Terima
\end{tabular}




\begin{tabular}{lllllll}
\hline 11 & PKR11 & S1 & Tidak & Ringan & Tolak \\
12 & PKR12 & S1 & Ada & Berat & Tolak \\
\hline
\end{tabular}

Tabel 5.1 memperlihatkan sebuah decision system sederhana hanya terdiri dari $-\mathrm{n}$ objek, objeknya pencari kerja disingkat PKR1,PKR 2,PKR 3,...PKR12 dan kriterianya Pendidikan, Kompetensi, Diagnosa Mental, sedangkan keputusan Decision Atribute.

b. Equivalence Class

TABEL 6. Equivalence Class

\begin{tabular}{lllllr}
\hline Class & Pendidikan & Kompetensi & \multicolumn{1}{c}{ Mental } & Keputusan & Jumlah \\
\hline EC1 & SMA & Ada & Ringan & Terima & 8 \\
EC2 & SMA & Ada & Ringan & Tolak & 5 \\
EC3 & SMA & Ada & Berat & Terima & 1 \\
EC4 & SMK & Tidak & Ringan & Tolak & 1 \\
EC5 & SMK & Tidak & Ringan & Terima & 1 \\
EC6 & D3 & Ada & Ringan & Terima & 8 \\
EC7 & D3 & Ada & Sedang & Tolak & 2 \\
EC8 & D3 & Tidak & Sedang & Tolak & 1 \\
EC9 & D3 & Tidak & Ringan & Tolak & 1 \\
EC10 & S1 & Ada & Ringan & Terima & 14 \\
EC11 & S1 & Tidak & Ringan & Tolak & 3 \\
EC12 & S1 & Ada & Berat & Tolak & 1 \\
\hline
\end{tabular}

Hasil penyederhanaan equivalence class disederhanakan dalam numerical representation agar tidak terjadi interdeminacy terhadap keputusan yang berbeda, kolom kanan mengindikasikan jumlah objek pada decision system unutk class yang sama.

TABEL 7. Numerical Representation

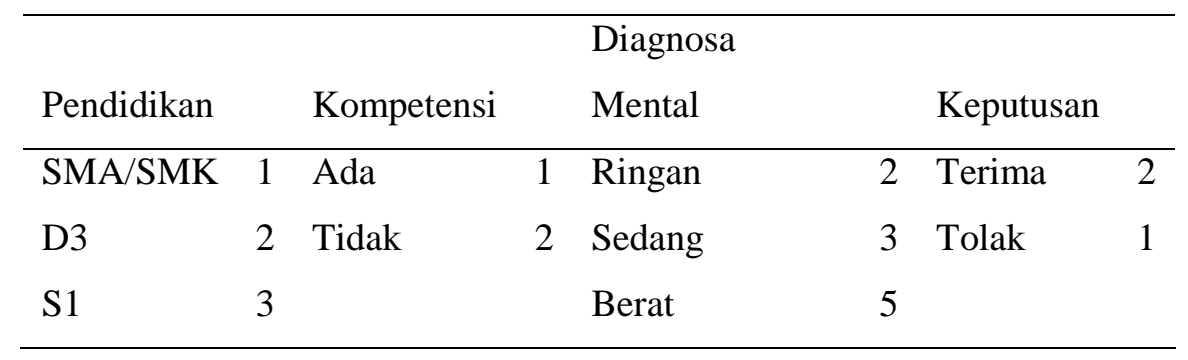


TABEL 8. Hasil Numerical Presentation

\begin{tabular}{cccccc}
\hline Class & Pendidikan & Kompetensi & Diagnosa Mental & Keputusan & Jumlah \\
\hline EC1 & 1 & 1 & 2 & 2 & 8 \\
EC2 & 1 & 1 & 2 & 1 & 5 \\
EC3 & 1 & 1 & 5 & 2 & 1 \\
EC4 & 1 & 2 & 2 & 1 & 1 \\
EC5 & 1 & 2 & 2 & 2 & 1 \\
EC6 & 2 & 1 & 2 & 2 & 8 \\
EC7 & 2 & 1 & 3 & 1 & 2 \\
EC8 & 2 & 2 & 3 & 1 & 1 \\
EC9 & 2 & 2 & 2 & 1 & 1 \\
EC10 & 3 & 1 & 2 & 2 & 14 \\
EC11 & 3 & 2 & 2 & 1 & 3 \\
EC12 & 3 & 1 & 5 & 1 & 1 \\
\hline
\end{tabular}

c. Discernability Matrix atau Discernability Matrix Modulo D

Untuk menghitung Discernability Matrix atau Discernability Matrix modulo D, Atribut dimodelkan Pendidikan (A), Kompetensi (B), dan Diagnosa Mental (C) Seperti tabel dibawah ini

TABEL 9 . Permodelan Discernability Matrix

\begin{tabular}{|c|c|c|c|c|}
\hline & \multicolumn{3}{|c|}{ Atribut Kondisi } & Atribut Keputusan \\
\hline Class & A & B & $\mathrm{C}$ & Keputusan \\
\hline $\mathrm{EC} 1$ & SMA & Ada & Ringan & Terima \\
\hline $\mathrm{EC} 2$ & SMA & Ada & Ringan & Tolak \\
\hline EC3 & SMA & Ada & Berat & Terima \\
\hline $\mathrm{EC} 4$ & SMK & Tidak & Ringan & Tolak \\
\hline EC5 & SMK & Tidak & Ringan & Terima \\
\hline EC6 & D3 & Ada & Ringan & Terima \\
\hline EC7 & D3 & Ada & Sedang & Tolak \\
\hline EC8 & D3 & Tidak & Sedang & Tolak \\
\hline EC9 & D3 & Tidak & Ringan & Tolak \\
\hline EC10 & S1 & Ada & Ringan & Terima \\
\hline EC11 & S1 & Tidak & Ringan & Tolak \\
\hline
\end{tabular}




EC12 S1 Ada Berat Tolak

Untuk mendapatkan nilai Discernability Matrix yaitu dengan mengklasifikasikan atribut yang berbeda antara objek $-\mathrm{i}$ ke objek $-\mathrm{j}$. jika ada perbedaan atribut class maka dituliskan Discernability Matrix ,sedangkan jika atribut class sama ditulis X.

TABEL 10 .Discernability Matrix

\begin{tabular}{|c|c|c|c|c|c|c|c|c|c|c|c|c|}
\hline Class & EC1 & EC2 & EC3 & EC4 & EC5 & EC6 & EC7 & EC8 & EC9 & EC10 & EC11 & EC12 \\
\hline EC1 & X & X & C & B & B & A & AC & $\mathrm{ABC}$ & $\mathrm{AB}$ & A & $\mathrm{AB}$ & $\mathrm{AC}$ \\
\hline EC2 & X & X & C & B & B & A & AC & $\mathrm{ABC}$ & $\mathrm{AB}$ & A & $A B$ & AC \\
\hline EC3 & C & C & X & BC & BC & $\mathrm{AC}$ & $\mathrm{AC}$ & $\mathrm{ABC}$ & $\mathrm{ABC}$ & $\mathrm{AC}$ & $\mathrm{ABC}$ & A \\
\hline EC4 & B & B & BC & X & X & $A B$ & $\mathrm{ABC}$ & AC & A & $\mathrm{AB}$ & A & $\mathrm{ABC}$ \\
\hline EC5 & B & B & BC & X & $X$ & $\mathrm{AB}$ & $\mathrm{ABC}$ & AC & A & $\mathrm{AB}$ & A & $\mathrm{ABC}$ \\
\hline EC6 & A & A & AC & $\mathrm{AB}$ & $A B$ & X & C & BC & B & A & $\mathrm{AB}$ & $\mathrm{AC}$ \\
\hline EC7 & AC & AC & AC & $\mathrm{ABC}$ & $\mathrm{ABC}$ & C & $X$ & B & $\mathrm{BC}$ & AC & $\mathrm{ABC}$ & $\mathrm{AC}$ \\
\hline EC8 & $\mathrm{ABC}$ & $\mathrm{ABC}$ & $\mathrm{ABC}$ & AC & $\mathrm{AC}$ & BC & B & X & C & $\mathrm{ABC}$ & AC & $\mathrm{ABC}$ \\
\hline EC9 & $\mathrm{AB}$ & $\mathrm{AB}$ & $\mathrm{ABC}$ & A & A & B & BC & C & $X$ & $\mathrm{AB}$ & A & $\mathrm{ABC}$ \\
\hline EC10 & A & A & AC & $\mathrm{AB}$ & $\mathrm{AB}$ & A & AC & $\mathrm{ABC}$ & $\mathrm{AB}$ & $X$ & B & $\mathrm{C}$ \\
\hline EC11 & $\mathrm{AB}$ & $\mathrm{AB}$ & $\mathrm{ABC}$ & A & A & $\mathrm{AB}$ & $\mathrm{ABC}$ & AC & A & B & X & BC \\
\hline EC12 & AC & AC & A & $\mathrm{ABC}$ & $\mathrm{ABC}$ & AC & AC & $\mathrm{ABC}$ & $\mathrm{ABC}$ & C & BC & $X$ \\
\hline
\end{tabular}

Untuk mendapatkan nilai Discernability Matrix Modulo D yaitu dengan mengklasifikasikan atribut yang berbeda antara objek $-\mathrm{i}$ ke objek $-\mathrm{j}$ berdasarkan decision atribut. jika keputusan sama dituliskan tanda $X$, jika berbeda tuliskan atribut perbedaannya.

TABEL 11. Discernability Matrix Modulo D

\begin{tabular}{|c|c|c|c|c|c|c|c|c|c|c|c|c|}
\hline Class & EC1 & EC2 & EC3 & EC4 & EC5 & EC6 & EC7 & EC8 & EC9 & EC10 & EC11 & EC12 \\
\hline EC1 & $\mathrm{X}$ & $\mathrm{X}$ & $\mathrm{X}$ & $\mathrm{B}$ & $\mathrm{X}$ & $\mathrm{X}$ & $\mathrm{AC}$ & $\mathrm{ABC}$ & $\mathrm{AB}$ & $\mathrm{X}$ & $\mathrm{AB}$ & $\mathrm{AC}$ \\
\hline EC2 & $\mathrm{X}$ & $\mathrm{X}$ & $\mathrm{C}$ & $\mathrm{X}$ & $\mathrm{B}$ & $\mathrm{A}$ & $\mathrm{X}$ & $\mathrm{X}$ & $\mathrm{X}$ & $\mathrm{A}$ & $\mathrm{X}$ & $\mathrm{X}$ \\
\hline EC3 & $\mathrm{X}$ & $\mathrm{C}$ & $\mathrm{X}$ & $\mathrm{BC}$ & $\mathrm{X}$ & $\mathrm{X}$ & $\mathrm{AC}$ & $\mathrm{ABC}$ & $\mathrm{ABC}$ & $\mathrm{X}$ & $\mathrm{ABC}$ & $\mathrm{A}$ \\
\hline EC4 & $\mathrm{B}$ & $\mathrm{X}$ & $\mathrm{BC}$ & $\mathrm{X}$ & $\mathrm{X}$ & $\mathrm{AB}$ & $\mathrm{X}$ & $\mathrm{X}$ & $\mathrm{X}$ & $\mathrm{AB}$ & $\mathrm{X}$ & $\mathrm{X}$ \\
\hline EC5 & $\mathrm{X}$ & $\mathrm{B}$ & $\mathrm{X}$ & $\mathrm{X}$ & $\mathrm{X}$ & $\mathrm{X}$ & $\mathrm{ABC}$ & $\mathrm{AC}$ & $\mathrm{A}$ & $\mathrm{X}$ & $\mathrm{A}$ & $\mathrm{ABC}$ \\
\hline EC6 & $\mathrm{X}$ & $\mathrm{A}$ & $\mathrm{X}$ & $\mathrm{AB}$ & $\mathrm{X}$ & $\mathrm{X}$ & $\mathrm{C}$ & $\mathrm{BC}$ & $\mathrm{B}$ & $\mathrm{X}$ & $\mathrm{AB}$ & $\mathrm{AC}$ \\
\hline EC7 & $\mathrm{AC}$ & $\mathrm{X}$ & $\mathrm{AC}$ & $\mathrm{X}$ & $\mathrm{ABC}$ & $\mathrm{C}$ & $\mathrm{X}$ & $\mathrm{X}$ & $\mathrm{X}$ & $\mathrm{AC}$ & $\mathrm{X}$ & $\mathrm{X}$ \\
\hline EC8 & $\mathrm{ABC}$ & $\mathrm{X}$ & $\mathrm{ABC}$ & $\mathrm{X}$ & $\mathrm{AC}$ & $\mathrm{BC}$ & $\mathrm{X}$ & $\mathrm{X}$ & $\mathrm{X}$ & $\mathrm{ABC}$ & $\mathrm{X}$ & $\mathrm{X}$ \\
\hline EC9 & $\mathrm{AB}$ & $\mathrm{X}$ & $\mathrm{ABC}$ & $\mathrm{X}$ & $\mathrm{A}$ & $\mathrm{B}$ & $\mathrm{X}$ & $\mathrm{X}$ & $\mathrm{X}$ & $\mathrm{AB}$ & $\mathrm{X}$ & $\mathrm{X}$ \\
\hline
\end{tabular}




\begin{tabular}{|c|c|c|c|c|c|c|c|c|c|c|c|c|} 
EC10 & $\mathrm{X}$ & $\mathrm{A}$ & $\mathrm{X}$ & $\mathrm{AB}$ & $\mathrm{X}$ & $\mathrm{X}$ & $\mathrm{AC}$ & $\mathrm{ABC}$ & $\mathrm{AB}$ & $\mathrm{X}$ & $\mathrm{B}$ & $\mathrm{C}$ \\
\hline $\mathrm{EC} 11$ & $\mathrm{AB}$ & $\mathrm{X}$ & $\mathrm{ABC}$ & $\mathrm{X}$ & $\mathrm{A}$ & $\mathrm{AB}$ & $\mathrm{X}$ & $\mathrm{X}$ & $\mathrm{X}$ & $\mathrm{B}$ & $\mathrm{X}$ & $\mathrm{X}$ \\
\hline $\mathrm{EC} 12$ & $\mathrm{AC}$ & $\mathrm{X}$ & $\mathrm{A}$ & $\mathrm{X}$ & $\mathrm{ABC}$ & $\mathrm{AC}$ & $\mathrm{X}$ & $\mathrm{X}$ & $\mathrm{X}$ & $\mathrm{C}$ & $\mathrm{X}$ & $\mathrm{X}$ \\
\hline
\end{tabular}

d. Reduct

Berdasarkan Discernability Matrix Modulo D ditulis sebagai formula CNF of Boolean Function.Gunakan Aljabar Boolean untuk mencari prime implication. Berikut hasil proses reduction nya :

TABEL 12. Hasil reduct

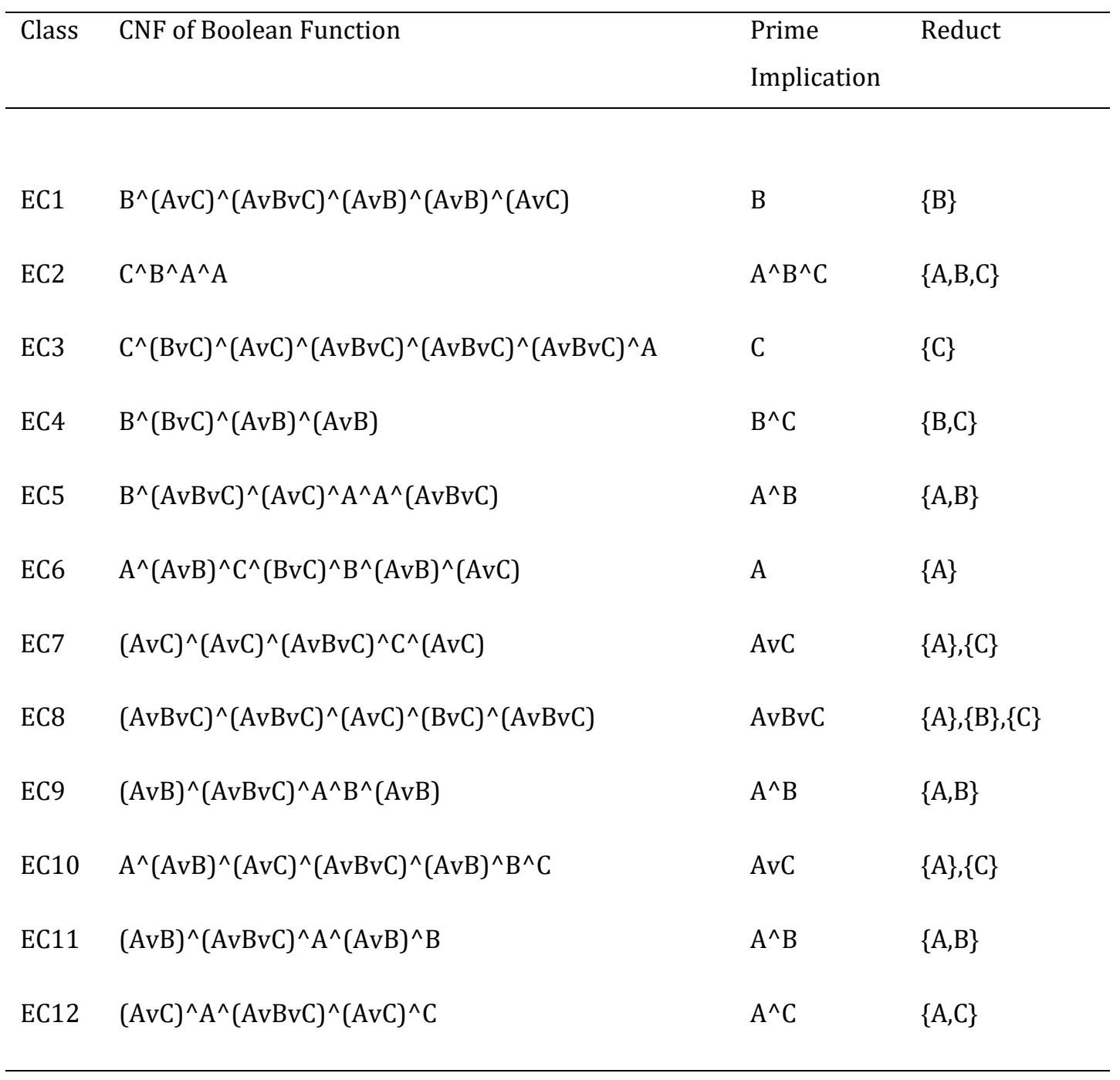

Jika dimodelkan reductnya dalam bentuk penjelasan sesuai 12 sampel analisis kriteria Menghasilkan 7reduct dari proses penyeleksian reduct menggunakan metode Rough Set sebagai berikut :

1. $\quad\{$ Pendidikan Terakhir $\}=\{\mathrm{A}\}$

2. $\quad\{$ Pendidikan Terakhir, Diagnosa Mental $\}=\{\mathrm{A}\},\{\mathrm{C}\}$

3. $\quad\{$ Kompetensi, Diagnosa Mental $\}=\{B, C\}$

4. $\{$ Diagnosa Mental $\}=\{C\}$ 
5. $\quad\{$ Pendidikan Terakhir, Kompetensi $\}=\{\mathrm{A}, \mathrm{B}\}$

6. $\quad\{$ Pendidikan Terakhir, Kompetensi, Diagnosa Mental $\}=\{A, B, C\}$

7. $\quad\{$ Kompetensi $\}=\{B\}$

e. Rule

Setelah didapatkan hasil reduction,maka langkah terakir menentukan General rules menggunakan tools rosseta 1.4.41 dimana tiap tiap equivalice class di modelkan Pendidikan $\{\mathrm{A}\}$, Kompetensi $\{\mathrm{B}\}$, Diagnosa Mental $\{\mathrm{C}\}$.Adapun generation rule nya sebagai berikut:

1. Pendidikan Terakhir(SMK) $=>$ Keputusan(Tolak) OR Keputusan(Terima)

2. Pendidikan Terakhir(S1) $=>$ Keputusan(Terima) OR Keputusan(Tolak)

3. Pendidikan Terakhir(D3) $=>$ Keputusan(Terima) OR Keputusan(Tolak)

4. Pendidikan Terakhir(SMA) $=>$ Keputusan(Terima) OR Keputusan(Tolak)

5. Pendidikan Terakhir(SMA) AND Diagnosa Mental(Berat) $\Rightarrow>$ Keputusan(Terima)

6. Pendidikan Terakhir(SMA) AND Diagnosa Mental(Ringan) $\Rightarrow$ Keputusan(Terima) OR Keputusan(Tolak)

7. Pendidikan Terakhir(S1) AND Diagnosa Mental(Berat) $\Rightarrow$ Keputusan(Tolak)

8. Pendidikan Terakhir(S1) AND Diagnosa Mental(Ringan) $\Rightarrow$ Keputusan(Terima) OR Keputusan(Tolak)

9. Pendidikan Terakhir(D3) AND Diagnosa Mental(Ringan) $\Rightarrow$ Keputusan(Terima) OR Keputusan(Tolak)

10. Kompetensi(Ada) AND Diagnosa Mental(Ringan) $\Rightarrow$ Keputusan(Terima) OR Keputusan(Tolak)

11. Kompetensi(Tidak) AND Diagnosa Mental(Ringan) $\Rightarrow$ Keputusan(Tolak) OR Keputusan(Terima)

12. Diagnosa Mental(Sedang) $=>\operatorname{Keputusan}($ Tolak)

13. Diagnosa Mental(Berat) $=>$ Keputusan(Terima) OR Keputusan(Tolak)

14. Pendidikan Terakhir(D3) AND Kompetensi(Tidak) $=>$ Keputusan(Tolak)

15. Pendidikan Terakhir(S1) AND Kompetensi(Ada) $\Rightarrow$ Keputusan(Terima) OR Keputusan(Tolak)

16. Pendidikan Terakhir(S1) AND Kompetensi(Tidak) $\Rightarrow$ Keputusan(Tolak)

17. Pendidikan Terakhir(D3) AND Kompetensi(Ada) $\Rightarrow$ Keputusan(Terima) OR Keputusan(Tolak)

18. Pendidikan Terakhir(D3) AND Kompetensi(Ada) AND Diagnosa Mental(Ringan) => Keputusan(Terima)

19. Pendidikan Terakhir(S1) AND Kompetensi(Ada) AND Diagnosa Mental(Ringan) => Keputusan(Terima)

20. Kompetensi(Tidak) $=>$ Keputusan(Tolak) OR Keputusan(Terima)

21. Kompetensi(Ada) $\Rightarrow$ Keputusan(Terima) OR Keputusan(Tolak)

\subsection{Analisis Pengujian Tools Rosseta 1.4.4.1}

a. Decision System

Langkah ini menggunakan data data yang ada pada Microsoft excel dari 100 data pencari kerja sebagai data analisis yang diolah menggunakan tools rosseta 1.4.41 berikut gambarnya : 


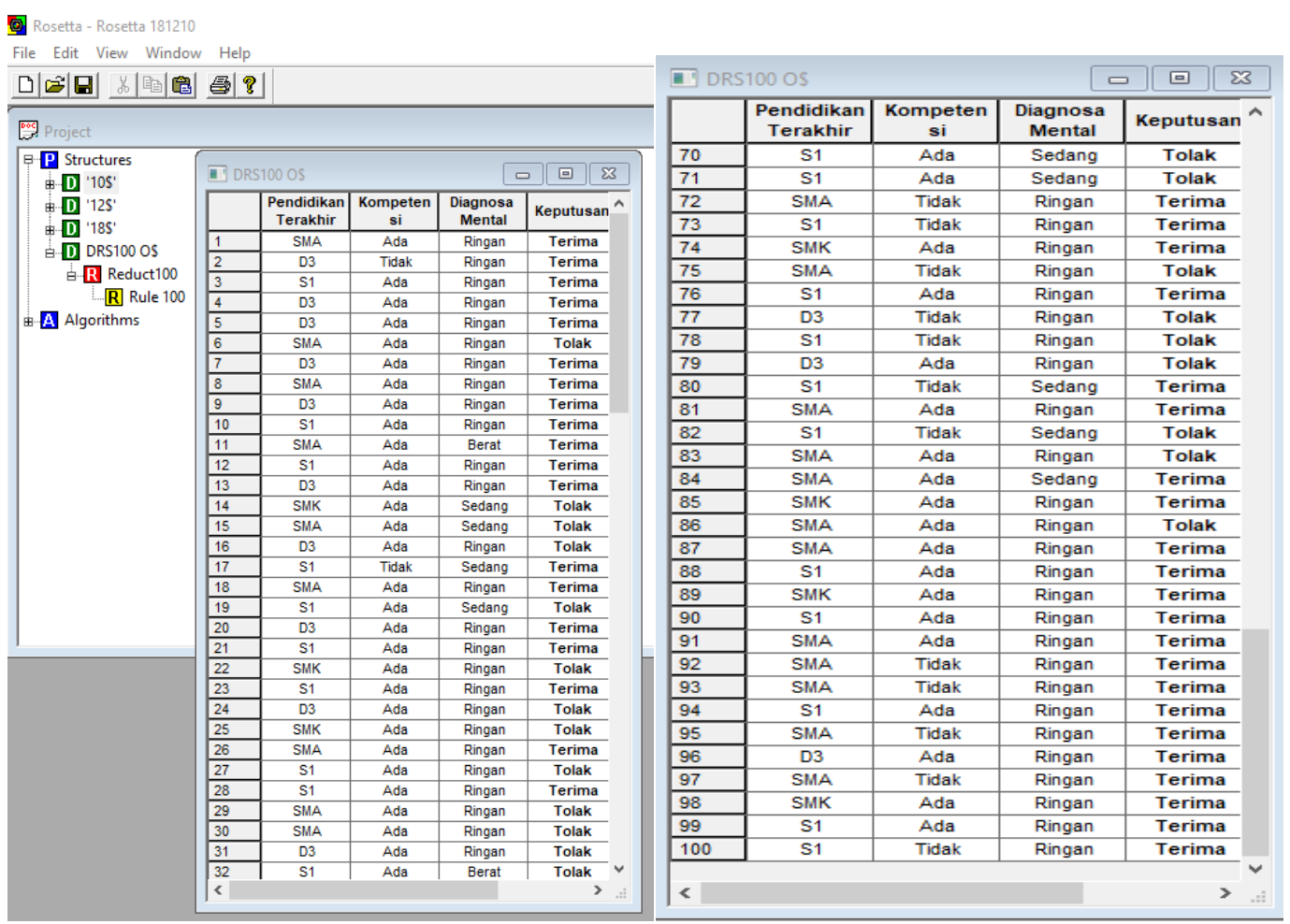

Gambar 3. Layar Project 100 Data

b. Proses Pencarian Reduct

Pada proses reduct data akan dideklarasikan dan dikombinasikan untuk mendapatkan General Rulesnya. Setelah itu direduce database 100 data pencari kerja menggunkan dynamic reduce (RSES) Maka menghasilkan reduce seperti dibawah ini :

\begin{tabular}{|l|l|l|l|l|}
\hline II Reduct100 & \multicolumn{1}{|c|}{ Reduct } & Support & Length \\
\hline & \multicolumn{1}{|c|}{ Len } \\
\hline 1 & $\{$ Pendidikan Terakhir, Diagnosa Mental\} & 59 & 2 \\
\hline 2 & $\{$ Kompetensi, Diagnosa Mental\} & 47 & 2 \\
\hline 3 & $\{$ Pendidikan Terakhir, Kompetensi\} & 55 & 2 \\
\hline 4 & $\{$ Pendidikan Terakhir, Kompetensi, Diagnosa Mental\} & 41 & 3 \\
\hline 5 & $\{$ Diagnosa Mental\} & 42 & 1 \\
\hline 6 & $\{$ Kompetensi\} & 5 & 1 \\
\hline 7 & $\{$ Pendidikan Terakhir\} & 22 & 1 \\
\hline
\end{tabular}

Gambar 4. Hasil 100 data yang direduct

c. Proses Pencarian General Rules

Kemudian terakhir dari reduce database 100 dengan hasil 7 reduce maka dimulai proses pencarian general rules dari tool rosseta 1.4 .41 sebagai berikut : 


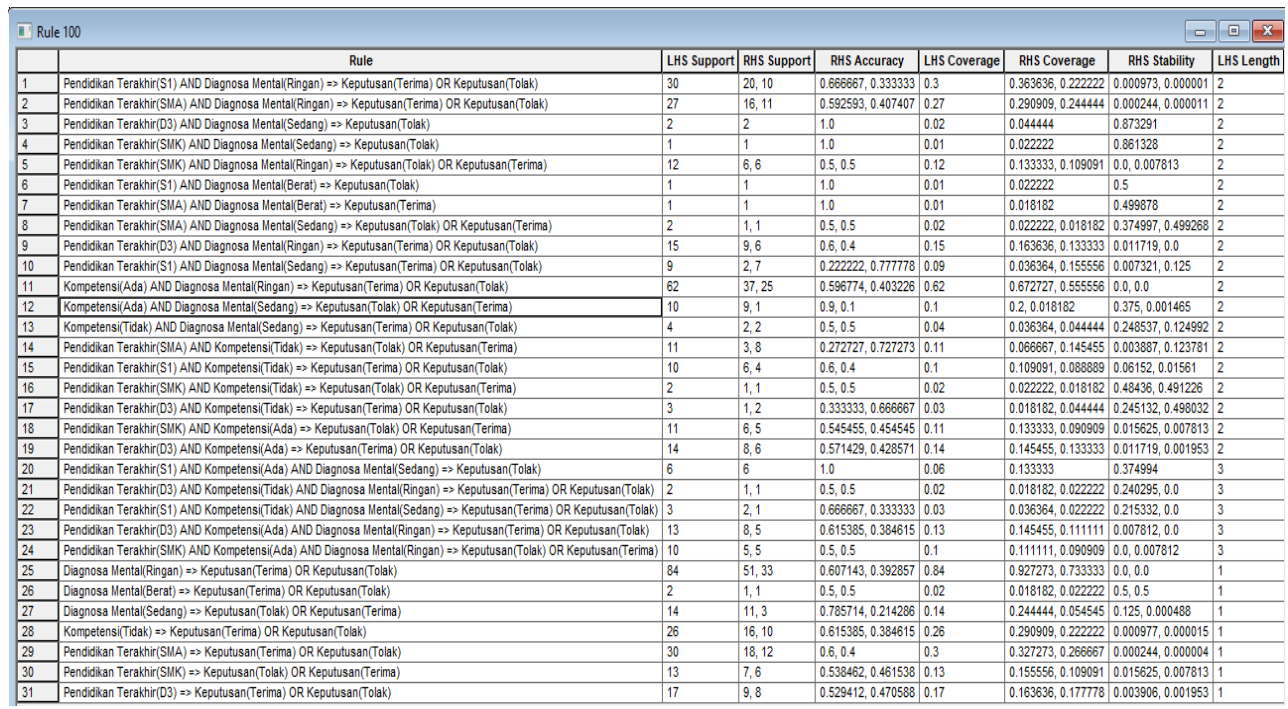

Gambar 5. Hasil 100 data yang direduct

Dalam pengujian 100 data input menghasilkan general rules sebagai berikut :

1. Pendidikan Terakhir(S1) AND Diagnosa Mental(Ringan) $\Rightarrow$ Keputusan(Terima) OR Keputusan(Tolak)

2. Pendidikan Terakhir(SMA) AND Diagnosa Mental(Ringan) $\Rightarrow$ Keputusan(Terima) OR Keputusan(Tolak)

3. Pendidikan Terakhir(D3) AND Diagnosa Mental(Sedang) $=>$ Keputusan(Tolak)

4. Pendidikan Terakhir(SMK) AND Diagnosa Mental(Sedang) $\Rightarrow$ Keputusan(Tolak)

5. Pendidikan Terakhir(SMK) AND Diagnosa Mental(Ringan) $\Rightarrow$ Keputusan(Tolak) OR Keputusan(Terima)

6. Pendidikan Terakhir(S1) AND Diagnosa Mental(Berat) $=>$ Keputusan(Tolak)

7. Pendidikan Terakhir(SMA) AND Diagnosa Mental(Berat) $=>$ Keputusan(Terima)

8. Pendidikan Terakhir(SMA) AND Diagnosa Mental(Sedang) $\Rightarrow$ Keputusan(Tolak) OR Keputusan(Terima)

9. Pendidikan Terakhir(D3) AND Diagnosa Mental(Ringan) $\Rightarrow$ Keputusan(Terima) OR Keputusan(Tolak)

10. Pendidikan Terakhir(S1) AND Diagnosa Mental(Sedang) $\Rightarrow$ Keputusan(Terima) OR Keputusan(Tolak)

11. Kompetensi(Ada) AND Diagnosa Mental(Ringan) $\Rightarrow$ Keputusan(Terima) OR Keputusan(Tolak)

12. Kompetensi(Ada) AND Diagnosa Mental(Sedang) $\Rightarrow$ Keputusan(Tolak) OR Keputusan(Terima)

13. Kompetensi(Tidak) AND Diagnosa Mental(Sedang) $\Rightarrow$ Keputusan(Terima) OR Keputusan(Tolak)

14. Pendidikan Terakhir(SMA) AND Kompetensi(Tidak) $\Rightarrow$ Keputusan(Tolak) OR Keputusan(Terima)

15. Pendidikan Terakhir(S1) AND Kompetensi(Tidak) $\Rightarrow$ Keputusan(Terima) OR Keputusan(Tolak)

16. Pendidikan Terakhir(SMK) AND Kompetensi(Tidak) $\Rightarrow$ Keputusan(Tolak) OR Keputusan(Terima)

17. Pendidikan Terakhir(D3) AND Kompetensi(Tidak) $\Rightarrow$ Keputusan(Terima) OR Keputusan(Tolak)

18. Pendidikan Terakhir(SMK) AND Kompetensi(Ada) $\Rightarrow$ Keputusan(Tolak) OR Keputusan(Terima)

19. Pendidikan Terakhir(D3) AND Kompetensi(Ada) $\Rightarrow$ Keputusan(Terima) OR Keputusan(Tolak) 
20. Pendidikan Terakhir(S1) AND Kompetensi(Ada) AND Diagnosa Mental(Sedang) => Keputusan(Tolak)

21. Pendidikan Terakhir(D3) AND Kompetensi(Tidak) AND Diagnosa Mental(Ringan) => Keputusan(Terima) OR Keputusan(Tolak)

22. Pendidikan Terakhir(S1) AND Kompetensi(Tidak) AND Diagnosa Mental(Sedang) => Keputusan(Terima) OR Keputusan(Tolak)

23. Pendidikan Terakhir(D3) AND Kompetensi(Ada) AND Diagnosa Mental(Ringan) => Keputusan(Terima) OR Keputusan(Tolak)

24. Pendidikan Terakhir(SMK) AND Kompetensi(Ada) AND Diagnosa Mental(Ringan) => Keputusan(Tolak) OR Keputusan(Terima)

25. Diagnosa Mental(Ringan) $\Rightarrow>$ Keputusan(Terima) OR Keputusan(Tolak)

26. Diagnosa Mental(Berat) $=>$ Keputusan(Terima) OR Keputusan(Tolak)

27. Diagnosa Mental (Sedang) $\Rightarrow$ Keputusan(Tolak) OR Keputusan(Terima)

28. Kompetens i(Tidak) $=>$ Keputusan(Terima) OR Keputusan(Tolak)

29. Pendidikan Terakhir (SMA) $\Rightarrow$ Keputusan(Terima) OR Keputusan(Tolak)

30. Pendidikan Terakhir (SMK) $=>$ Keputusan(Tolak) OR Keputusan(Terima)

31. Pendidikan Terakhir (D3) $=>$ Keputusan (Terima) OR Keputusan(Tolak).

\section{KESIMPULAN}

Pengujian dari 100 database pencari kerja dengan tools rosseta 1.4.41 terdeteksi dengan rule rule yang dihasilkan reduct sebanyak 7 reduce di ekstraksi menjadi knowledge 31 general rules sedangkan pengujian dari pengelolaan menggunakan data mining sebanyak 200 data pencari kerja setelah divalidasi menjadi 100 data pencari kerja kemudian diolah menggunakan metode Rough Set menjadi 12 data analisis sebagai information system terdeteksi rule rule menghasilkan 7 reduct diekstraksi menjadi knowledge 21 general rules.Sehingga baik dengan metode Rough Set maupun tools rosseta 1.4.41 sama sama menghasilkan 7 reduce tetapi knowledge yang bervariasi.sehingga reduce bisa mewakili untuk mengambil keputusan dari pencari kerj untuk instansi terkait.dari masing-masing hasil yang didapatkan dari penelitian yang dibahas. Berdasarkan perbandingan pengujian baik dengan metode Rough Set maupun menggunakan tools rosseta 1.4.41 sudah optimal dalam menghasil reduce hasil dari tiap tiap equivalence class walaupun ekstraksi knowledge untuk general rules sama sama mendekati rulenya masing masing karena proses metode yg berbeda. Maka dengan adanya suatu metode Rough Set sangat membantu pihak -pihak terkait dalam proses pengambilan keputusan pencari kerja.

\section{UCAPAN TERIMAKASIH}

Terimakasih kepada pihak pemberi dana penelitian, kepada direktorat Riset dan Pengabdian Masyarakat,Direktorat Jenderal Penguatan Riset dan Pengembangan, dan Kementerian Riset, Teknologi, dan Pendidikan Tinggi .

\section{DAFTAR PUSTAKA}

[1]. A. Fadli, M. I. Zulfa, and Y. Ramadhani, 2018. Perbandingan Unjuk Kerja Algoritma Klasifikasi Data Mining dalam Sistem Peringatan Dini Ketepatan Waktu Studi Mahasiswa. Jurnal Teknologi dan Sistem Komputer, Vol. 6, No. 4, Oktober, pp. 158163.

[2]. Ahmad, Abu, 2017. Mengenal Artificial Intelligence, Machine Learning, Neural Network, dan Deep Learning. Jurnal Teknologi Indonesia. 
[3]. Buaton, R., 2013. Metode Menyelesaikan Data Mining, Sistem Pakar dan Sistem Pendukung Keputusan. Medan: MK Relita-STMIK Kaputama.

[4]. Eko Prasetyo, 2012. Penerapan Data Mining-Konsep dan Aplikasi Menggunakan Matlab 1, Yogyakarta:C V Andi Offset. Hal xxiv+360..

[5]. Fauzi, R., 2016. Penerapan Data Mining Menggunakan Metode Rough Set dalam Pengambilan Keputusan Penyebab Pengangguran: Studi Kasus di Yayasan Aman Kota Padang. Universitas Putra Indonesia-YPTK Padang.

[6]. Kurniawati, S., 2015. Penerapan Metode Rough Set Pada Peningkatan Kepuasan Konsumen Terhadap Kualitas Pelayanan Hotel. Majalah Jurnal Informasi dan Teknologi Ilmiah (INTI), Vol. V, No. 2, Januari, ISSN: 2339-210X, hal 138-142.

[7]. Badan Pusat Statistik Kota Padang, Sumatera Barat, 2017. Statistik Indonesia Tahun 2017. Padang

[8].

Indonesia Tahun 2018. Padang

2018. Statistik

[9].

Indonesia Tahun 2019. Padang

[10]. Santoso B (2013) "Data Mining, Teknik Pemanfaatan Data Untuk Keperluan Bisnis,Yogyakarta, Penerbit Graha Ilmu.10"

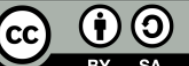

ZONAsi: Jurnal Sistem Informasi

is licensed under a Creative Commons Attribution International (CC BY-SA 4.0) 